\title{
Characteristic and Adoption Behaviour of Pomegranate Growers in Barmer District Rajasthan, India
}

\author{
B.R. Morwal, Pradeep Pagaria and Shayam Das* \\ Krishi Vigyan Kendra - Danta - Barmer (Raj.) 344001, India \\ *Corresponding author
}

\begin{tabular}{|l|}
\hline Ke y w o r d s \\
Pomegranate \\
(Punica granatum \\
$\begin{array}{l}\text { L.), Fruit } \\
\text { consumption }\end{array}$ \\
\hline Article Info \\
\hline $\begin{array}{l}\text { Accepted: } \\
18 \text { August } 2018 \\
\text { Available Online: } \\
\text { 10 September } 2018\end{array}$ \\
\hline
\end{tabular}

\section{Introduction}

Pomegranate (Punica granatum L.) belonging to family punicaceae is an economically important fruit crop of arid and semi-arid regions of the world. It is in great demand for fresh fruit consumption in national and international markets. There has been enormous increase in area, production and export of pomegranate worldwide during the past decades owing to its immense medicinal/ therapeutic values and higher remuneration. Pomegranate is a good source of protein, carbohydrate, minerals, antioxidants, vitamin A, B and C. In India also, it is an important fruit crop for arid and semi-arid regions. Maharashtra is the leading state in India in 
area and production of pomegranate followed by Karnataka, Andhra Pradesh, Rajasthan and Rajasthan (Ram Chandra et al., 8).

In Rajasthan area under pomegranate has increased continuously and in the same period the production has also increased. Pomegranate is nutritionally superior and capable of producing higher yield and good return. It is considered as the most potential fruit crop based on export volume and value. Barmer (Rajasthan) has an established

Export market and poses bright opportunities for export in the international market whether in fresh or processed form. Similarly, pomegranate industry has provided livelihood opportunities to its growers and those involved in its marketing channel. Over half of the world pomegranate is produced by India, while its export share in the world market is meager only 5.3 per cent. Hence, there is a good opportunity for the pomegranate growers and those who are involved in marketing and processing business.

In view of these facts, it was highly considered necessary to carry out the study with the following specific objectives: to study the personal, socio-economic and situational, extension communication and psychological profile of pomegranate growers and to assess the extent of adoption of recommended pomegranate production technologies by the pomegranate growers.

This investigation may also be helpful to the researchers with respect to improvement of pomegranate varieties for particular traits in arid regions.

\section{Materials and Methods}

The investigation was undertaken in Balotra, Gudamalani and Sindhri block of Barmer district of Rajasthan state. From this Three
Block, total ten (15) villages were selected purposively on the basis of more number of pomegranate growers in the village. From each village, 10 (5) pomegranate growers were selected. Thus, the sample size of the investigation was one hundred (seventy five). The farmers doing pomegranate cultivation since last five years were selected randomly. Ex-post facto research design was used for the study and multi-stage random sampling technique was used for the selection of districts, Block and villages.

An interview schedule was prepared containing information regarding different variables. The data were collected by personal interview. The data so collected were coded, classified, tabulated and analyzed in order to make the findings meaningful. The fin dings of the study and conclusions are summarized as below.

\section{Observations and analysis}

The result obtained from the present investigation has been discussed below:

\section{Distribution of the respondents according to their selected characteristic}

Age

The data presented in Table 1 indicate that 52.00 per cent of the respondents were in the middle age group, while 26.00 per cent were in the young age group. The remaining 22.00 per cent of the respondents were from the old age group. This finding is in conformity with the observation of Chothani (1999).

\section{Education}

The data presented in Table 1 indicate that 16.00 per cent of the respondents possessed Primary level of education, whereas 42.00 and 29.00 per cent of the respondents had 
secondary and higher secondary level of education, respectively. The Bachelor's degree was possessed by only 12.00 per cent.

It was interesting to note that only 1.00 per cent of the respondents were illiterate. Similar findings were reported by Chothani (1999).

\section{Land holding}

As shown in Table 1, 61.00 per cent of the pomegranate growers had a medium size of land holding. Remaining 30.00 per cent and 9.00 had small and big size of land holding, respectively. The finding of Chothani (1999) is in conformity with the present finding.

\section{Area under pomegranate}

The data pertaining to the area under pomegranate cultivation are given in Table 1 , which revealed that near to half of the respondents (45.00 per cent) possessed, more than 75.00 per cent land under pomegranate cultivation, whereas 22.00 per cent had land ranging from 50.00 to 75.00 per cent out of total land possession, while only 12.00 per cent and 21.00 per cent of pomegranate growers were fall in the category up to 25.00 per cent and 25.00 to 50.00 per cent of land possession, respectively.

\section{Irrigation facilities}

The data pertaining to the irrigation facility are given in Table 1, which revealed that 66.00 per cent of the pomegranate growers had a medium level of irrigation facility. While 28.00 per cent and 6.00 per cent were in the category of less and more irrigation facilities, respectively. Majority of pomegranate growers either irrigate their plantation by means of bore well or canal water. Similar findings were reported by Jadav (2005).

Socio-economic, situational and extension

\section{communication variables}

\section{Family size}

As shown in Table 2, 76.00 per cent of the respondents had small size of family, while 24.00 per cent of respondents were in the category of large size of family.

Similar results were reported by Jadav (2005).

\section{Annual income}

From the data presented in Table 2, it is observed that 58.00 per cent of the pomegranate growers had the medium level of income ranging from Rs. 1.00 to 3.00 lacs followed by 27.00 per cent of the respondents had the income up to Rs. 1.00 lac and only 15.00 per cent had income above Rs. 5.00 lacs. The finding was confirmed by Jadav (2005)

\section{Cropping intensity}

The data presented in Table 2 clearly indicate that 68.00 per cent of the pomegranate growers had medium cropping intensity; whereas 12.00 per cent and 20.00 per cent had low and high level of cropping intensity, respectively.

This finding was in conformity with the findings of Jadav (2005).

\section{Social participation}

The data presented in Table 2 revealed that more than four fifth $(82.00$ per cent $)$ of the respondents had medium social participation followed by low ( 8.00 per cent) and high (10.00 per cent) social participation.

The similar findings were observed by Chothani (1999) and Jadav (2005). 
Table.1 Personal variables pomegranate growers $(n=100)$

\begin{tabular}{|c|c|c|c|c|}
\hline Sr. No. & Characteristics & Category & Frequency & Per cent \\
\hline \multirow[t]{3}{*}{1.} & Age & Young (up to 35 years) & 26 & 26.00 \\
\hline & & Middle (36 to 50 years) & 52 & 52.00 \\
\hline & & Old (Above 50 years) & 22 & 22.00 \\
\hline \multirow[t]{5}{*}{2.} & Education & Illiterate & 1 & 1.00 \\
\hline & & Primary education (up to $7^{\text {th }}$ Std.) & 16 & 16.00 \\
\hline & & Secondary education ( $8^{\text {th }}$ to $10^{\text {th }} \mathrm{Std}$.) & 42 & 42.00 \\
\hline & & Higher secondary education ( $11^{\text {th }}$ to $12^{\text {th }}$ Std.) & 29 & 29.00 \\
\hline & & College education & 12 & 12.00 \\
\hline \multirow[t]{3}{*}{3.} & Land holding & Small (1 to 2 ha) & 30 & 30.00 \\
\hline & & Medium (2 to $10 \mathrm{ha}$ ) & 61 & 61.00 \\
\hline & & Big (above 10 ha) & 9 & 9.00 \\
\hline \multirow[t]{4}{*}{4.} & Area under pomegranate cultivation & Up to 25 per cent & 12 & 12.00 \\
\hline & & 25 to 50 per cent & 21 & 21.00 \\
\hline & & 50 to 75 per cent & 22 & 22.00 \\
\hline & & Above 75 per cent & 45 & 45.00 \\
\hline \multirow[t]{3}{*}{5.} & Irrigation facility & Less (up to 2 ha) & 28 & 28.00 \\
\hline & & Medium (2 to $10 \mathrm{ha}$ ) & 66 & 66.00 \\
\hline & & More (above 10 ha) & 06 & 6.00 \\
\hline
\end{tabular}

Table.2 Socio-economic, situational and extension communication variables $(n=100)$

\begin{tabular}{|c|c|c|c|c|}
\hline Sr. No. & Characteristics & Category & Frequency & Per cent \\
\hline \multirow[t]{2}{*}{1} & \multirow[t]{2}{*}{ Family size } & Small family (up to 5 members) & 76 & 76.00 \\
\hline & & Large family (above 5 members) & 24 & 24.00 \\
\hline \multirow[t]{3}{*}{2} & \multirow[t]{3}{*}{ Annual income (Rs.) } & Low (up to 1.00 lac) & 27 & 27.00 \\
\hline & & Medium (1.00 to 3.00 lacs) & 58 & 58.00 \\
\hline & & High (above 3.00 lacs) & 15 & 15.00 \\
\hline \multirow[t]{3}{*}{3} & \multirow[t]{3}{*}{ Cropping intensity } & Low (up to $1 \mathrm{ha}$ ) & 12 & 12.00 \\
\hline & & Medium (1 to 4 ha) & 68 & 68.00 \\
\hline & & High (above 4 ha) & 20 & 20.00 \\
\hline \multirow[t]{3}{*}{4} & \multirow[t]{3}{*}{ Social participation } & Low (member in one organization) & 08 & 8.00 \\
\hline & & Medium (member in more than one organization) & 82 & 82.00 \\
\hline & & High (members with office bearer) & 10 & 10.00 \\
\hline \multirow[t]{3}{*}{5} & \multirow{3}{*}{$\begin{array}{l}\text { Awareness regarding } \\
\text { value addition }\end{array}$} & Low (below 1.70) & 06 & 6.00 \\
\hline & & Medium(1.71-2.61) & 72 & 72.00 \\
\hline & & High (above 2.61) & 22 & 22.00 \\
\hline \multirow[t]{3}{*}{$\overline{6}$} & \multirow{3}{*}{$\begin{array}{l}\text { Pomegranate yield } \\
\text { index }\end{array}$} & Low (below 90.71) & 04 & 4.00 \\
\hline & & Medium $(90.72-110.12)$ & 76 & 76.00 \\
\hline & & High (above110.12) & 20 & 20.00 \\
\hline \multirow[t]{3}{*}{7.} & \multirow{3}{*}{$\begin{array}{l}\text { Employment } \\
\text { generation }\end{array}$} & Low (below 100 man days) & 05 & 5.00 \\
\hline & & Medium (101 - 150 man days) & 81 & 81.00 \\
\hline & & High (above 150 man days) & 24 & 24.00 \\
\hline \multirow[t]{3}{*}{8.} & \multirow{3}{*}{$\begin{array}{l}\text { Extension } \\
\text { participation }\end{array}$} & Low (up to 42.86 ) & 18 & 18.00 \\
\hline & & Medium (42.87-85.71) & 53 & 53.00 \\
\hline & & High (above 85.71) & 29 & 29.00 \\
\hline \multirow[t]{3}{*}{9.} & \multirow{3}{*}{ Mass media exposure } & Low (up to 9.06) & 22 & 22.00 \\
\hline & & Medium $(9.07-12.78)$ & 54 & 54.00 \\
\hline & & High (above 12.78 ) & 24 & 24.00 \\
\hline
\end{tabular}


Table.3 Psychological variables of pomegranate growers $(n=100)$

\begin{tabular}{|c|c|c|c|c|}
\hline Sr. No. & Characteristics & Category & Frequency & Per cent \\
\hline \multirow[t]{3}{*}{1.} & \multirow[t]{3}{*}{ Extent of adoption } & Low (up to 61.27 ) & 12 & 12.00 \\
\hline & & Medium (61.28-90.19) & 67 & 67.00 \\
\hline & & High (above 90.19) & 21 & 21.00 \\
\hline \multirow[t]{3}{*}{2.} & \multirow{3}{*}{$\begin{array}{l}\text { Management } \\
\text { orientation }\end{array}$} & Low (up to 32.97 ) & 10 & 10.00 \\
\hline & & Medium (32.98-42.55) & 65 & 65.00 \\
\hline & & High (above 42.55) & 25 & 25.00 \\
\hline \multirow[t]{3}{*}{3.} & \multirow[t]{3}{*}{ Innovativeness } & Poor (up to 1.84 ) & 15 & 15.00 \\
\hline & & Average (1.85-2.94) & 31 & 31.00 \\
\hline & & Best (above 2.94) & 54 & 54.00 \\
\hline \multirow[t]{3}{*}{4.} & \multirow[t]{3}{*}{ Progressiveness } & Poor (up to 6.63) & 08 & 8.00 \\
\hline & & Average (6.64-8.03) & 84 & 84.00 \\
\hline & & Best (above 8.03) & 08 & 8.00 \\
\hline \multirow[t]{3}{*}{5.} & \multirow{3}{*}{$\begin{array}{l}\text { Knowledge of } \\
\text { pomegranate growers }\end{array}$} & Low (up to 23.49) & 07 & 7.00 \\
\hline & & Medium (23.50-31.66) & 74 & 74.00 \\
\hline & & High (above 31.66) & 19 & 19.00 \\
\hline
\end{tabular}

Table.4 Practice wise extent of adoption of improved pomegranate production technology by pomegranate growers $(n=100)$

\begin{tabular}{|l|l|l|l|l|l|}
\hline Sr. No. & Practice & Weightage & Mean score & Percentage & Rank \\
\hline 1. & Intercultural operation & 12 & 6.45 & 53.75 & VIII \\
\hline 2. & Selection of variety & 2 & 2.00 & 100.00 & I \\
\hline 3. & Planting distance & 7 & 6.79 & 97.00 & II \\
\hline 4. & Organic manure & 11 & 4.71 & 42.77 & IX \\
\hline 5. & Chemical fertilizers & 12 & 10.41 & 86.75 & V \\
\hline 6. & Irrigation & 16 & 10.80 & 67.50 & VI \\
\hline 7. & Integrated pest management & 14 & 13.50 & 96.20 & III \\
\hline 8. & $\begin{array}{l}\text { Integrated disease } \\
\text { management }\end{array}$ & 15 & 13.85 & 92.33 & IV \\
\hline 9. & $\begin{array}{l}\text { Inter cropping } \\
\text { Use of hormones } \\
\text { paclabutrazol (Cultar) }\end{array}$ & $/ 3$ & 1.08 & 36.00 & X \\
\hline 10. & \begin{tabular}{l} 
Practice \\
\hline
\end{tabular} & 100 & 4.75 & 55.60 & VII \\
\hline
\end{tabular}

\section{Awareness regarding value addition}

It can be seen from the data presented in Table 2 that near to three fourth $(72.00$ per cent) of the respondents had medium level of awareness followed by high (22.00 per cent) and low (6.00 per cent) level of awareness regarding value addition.

\section{Pomegranate yield index}

The data presented in Table 2 clearly indicate that 76.00 per cent of the pomegranate growers had medium pomegranate yield index, whereas 20.00 per cent of respondents had high pomegranate yield index and only 4.00 per cent of the respondents had low level 
pomegranate yield index. Similar findings were reported by Jadav (2005).

\section{Employment generation}

The data presented in Table 2 revealed that majority of pomegranate growers $(81.00$ per cent) had medium employment generation, whereas 24.00 per cent of respondents had high employment generation and only 5.00 per cent of the respondents had low employment generation.

\section{Extension participation}

The data regarding extension participation are presented in Table 2, which revealed that 53.00 per cent of the pomegranate growers had medium extension participation, whereas 29.00 per cent and 18.00 per cent of them had high and low extension participation, respectively.

\section{Mass media exposure}

From perusal of the data presented in Table 2, it is clear that 54.00 per cent of the pomegranate growers had medium level of mass media exposure, whereas 24.00 per cent and 22.00 per cent of them had high and low level of mass media exposure. It can be concluded that majority (78.00 per cent) of the respondents had medium to high level of mass media exposure. This finding is in concurrence with the results of Jadav (2005).

\section{Psychological variables}

\section{Extent of adoption}

The data of Table 3 clearly indicate that majority of the respondents (67.00 per cent) possessed medium level of extent of adoption followed by high (21.00 per cent) and low (12.00 per cent) extent of adoption of recommended pomegranate production technology. This finding was in concurrence with the findings of Verma and Munshi (2003).

\section{Management orientation}

It can be observed from the data presented in Table 3 that majority of the respondents (65.00 per cent) were found in medium category of management orientation, while 25.00 per cent and 10.00 per cent of the pomegranate growers were found in high and low category of management orientation, respectively.

\section{Innovativeness}

The data in Table 3 revealed that the majority (54.00 per cent) of pomegranate growers had best level of innovativeness followed by average (31.00 per cent) and poor (15.00 per cent) level of innovativeness of pomegranate growers. This finding was in agreement with the observations of Kotadiya (2006).

\section{Progressiveness}

It is evident from the data presented in Table 3 that majority $(84.00$ per cent) of pomegranate growers had average level of progressiveness. This was followed by equal number ( 8.00 per cent) of respondents that fell in best and poor levels of progressiveness. Similar finding was reported by Kotadiya (2006).

\section{Knowledge of pomegranate growers}

It is evident from the data presented in Table 3 that the majority (74.00 per cent) of the respondents had average level of knowledge regarding improved pomegranate production technology followed by best (19.00 per cent) and poor (7.00 per cent) level, respectively. This finding is in line with the results of Kotadiya (2006). 
(Rank seventh, 55.60 per cent); intercultural operation (rank eights, 53.75 per cent); application of organic manure (rank ninth, 42.77 per cent) and intercropping (rank tenth, 36.00 per cent).

It can be summarized that the practices viz., variety, planting distance, integrated disease management, and integrated insects pests management were highly adopted by the pomegranate growers. While practices like intercropping and use of organic manure occupied almost last position in adoption.

Practice wise extent of adoption of improved pomegranate production technology by pomegranate growers

The practice wise scores were assigned to all 10 practices on the basis scores obtained by the respondents adopting particular practices. The mean scores were worked out for all the 10 practices. The mean score further converted into percentage and ranks were assigned to each practice. The overall mean percentage of 10 practices was 74.04 per cent (Table 4). These mean percentages were considered for distinguished more or less adopted practices. The results showed that 10 practices of technology adopted by pomegranate growers were arranged according to their ranks in descending order. The adoption of variety occupied first rank (100 per cent). This was followed by planting distance (rank second, 97.00 per cent); integrated pest management (rank third, 96.20 per cent); integrated diseases management (rank fourth, 92.33 per cent); chemical fertilizer (rank fifth, 86.75 per cent); irrigation facilities (rank sixth, 67.50 per cent); use of hormons

\section{References}

Chothani, S.B. (1999) Training needs of pomegranate orchard growers of Junagadh district, Rajasthan state. M.Sc. (Ag.) Thesis, Junagadh Agricultural University, JUNAGADH, RAJASTHAN (India).

Jadav, N.B. (2005) Managerial ability of pomegranate growers about scientific cultivation of pomegranate orchard. Ph.D. Thesis, Junagadh Agricultural University, JUNAGADH, RAJASTHAN (India).

Kota diya, D. G. (2006). Impact of integrated horticultural development programme in Junagadh district of Rajasthan State. Ph.D. Thesis, Junagadh Agricultural University, JUNAGADH, RAJASTHAN (India).

Verma, P.D. and Munshi, M.A. (2003) Socioeconomic impact of pomegranate industry on ruralities, Lead paper, National Seminar on Pomegranate, Junagadh Agricultural University, JUNAGADH, RAJASTHAN (India). June 14-15, 2003, Abstract pp.114-115.

\section{How to cite this article:}

Morwal, B.R., Pradeep Pagaria and Shayam Das. 2018. Characteristic and Adoption Behaviour of Pomegranate Growers in Barmer District Rajasthan, India. Int.J.Curr.Microbiol.App.Sci. 7(09): 2527-2533. doi: https://doi.org/10.20546/ijcmas.2018.709.314 